\title{
INFORMATION TECHNOLOGY TRENDS: A LONGITUDINAL STUDY OF TERMS USED IN ISSUES IN INFORMATION SYSTEMS TITLES
}

\author{
Alan Peslak, Penn State University, arp14@psu.edu
}

\begin{abstract}
This manuscript reviews information technology academic research topics over the past eighteen years in order to determine the trends of key topics and how they have risen and fallen over this extended period of time. The study reviews titles from all Issues in Information Systems volumes published by the International Association of Computer Information Systems from its inception in 2000 to 2017. The results from these nearly two thousand articles show significant changes in information topics over this almost 20 year period. Our study reviews these trends and serves as both an historical review of the changing IT research landscape as well as a summary of current and past major topics of research.
\end{abstract}

Keywords: technology trends, information systems, Information technology, information technology trends, topics, longitudinal

\section{INTRODUCTION}

Information technology is one of the most rapidly changing fields of discipline in the world today. The fast pace of advances in computing, processing power, memory, devices, artificial intelligence and communications has been staggering. Likewise, the study of information systems and technology has changed to try and understand, guide, and integrate the issues associated with this rapidly changing technology. There have been many changes in information technology over the years. Eason (2014) suggests that rapid information technology advances should revolutionize organizations. Lee, Son, and Kim (2016) have suggest that information communications and technology have changed so rapidly that we are dealing with stress and information technology fatigue. It is clear that information technology is changing but few studies have tried to understand specifically what is changing. This manuscript is an attempt to study the changes in information technology research that have taken place over the last 18 years by reviewing titles of over 1,900 articles published in the International Association of Computer Information Systems, Issues in Information Systems Journal.

\section{LITERATURE REVIEW}

There are two areas of research that our work builds upon: study of research article titles and content and study of information technology trends. First, the study of research article titles is well established in the literature. Jacques and Seibre (2010) studied research article titles in medical journals in order to determine variables or words that may affect the number of citations that an article receives. They found that citations increased when the title was longer, had a colon in the title and included an acronym. Citations were reduced when a country was mentioned in the title. Anthony (2001) studied research article titles in computer science. He studied different computer journals and found that specific content words aided in citations for specific sub-genres of computer science. He also noted the importance of prepositions after performing content analysis of the articles.

In addition, the study of trends in information technology has received extensive interest in the academic research community. Martin et al. (2011) studied technology trends in education over a period of seven years. Their work centered primarily on predicted trends versus actual results. They found that many predicted trends such as "social networks, user-created content, games, virtual worlds and mobile devices" did come to fruition but others such as "knowledge Web, learning objects and open content, context-awareness and ubiquitous computing" did not. The authors note that some technologies were delayed but may come about later. Goldzweig, et al. (2009) primarily studied trends in health information technology from 2004 to 2007 and focused their work on electronic health records (EHR) 
and patient focused applications. Hammant (1995) examined information technology trends in logistics and examined technology integration and flexibility, EDI, hardware, and communications technologies. Chao, et al. (2007) were one of the groups that studied technology trends and forecasts of technology over a longer period of time. They studied RFID by a historical review and bibliometric analysis from 1991 to 2005. Sawyer, \& Chen (2003) reviewed academic and industry ICT (Information and Communication Technology) trends over time and found large differences in many of the topics and technologies studied.

Finally, there are many popular press predictions issued every year on future trends in information technology. One such report from IEEE (2017) predicted the following technology trends will reach adoption in 2018: Deep learning, digital currencies, blockchain, industrial IoT, assisted transportation including self-driving vehicle technology, assisted and virtual reality, privacy, accelerators and cybersecurity and AI.

The results of the literature review supports the review of scholarly articles as a valid research tool. Also supported is the study of technology trends. The author could find no combination of these two elements in a single article. We thus propose that this manuscript offers a new contribution by combining research review and technology trends over an extended period of time. This study uniquely evaluates the current status of top technologies for research as well as their changes over the past two decades.

\section{METHODOLOGY}

The source for our research article analysis is the complete library of Issues in Information Systems. Issues in Information Systems has been published by the International Association of Computer Information Systems since the year 2000. According to their website, "Issues in Information Systems (IIS) journal is a refereed (double blind) serial publication (ISSN 1529-7314). IIS publishes the latest research in practice and pedagogical topics that focus on how information systems are used to support organizations or enhance the educational process." (Issues In Information Systems, 2018).

"IIS is listed in Cabell's Directory of Publishing Opportunities in Management and Marketing since the 8th Edition. In addition, IIS is indexed in EBSCO Host. IIS is the official publication of the IACIS Annual Conference. IIS is a refereed, serial publication of IACIS that is registered with the US Library of Congress (ISSN 1529-7314) and listed in the Eighth Edition of Cabell's Directory of Publishing Opportunities in Management and Marketing. Volume I of IIS was published with the 2000 IACIS Annual Conference. All submissions to IIS are double-blind refereed." (Issues In Information Systems, 2018).

"The mission and vision statements of IACIS are

Vision Statement: Our vision is to be one of the leading international academic information systems and technology professional organizations.

Mission Statement: We value activities that develop the knowledge and skills of information systems and technology academics, by providing a forum for networking and discussing research ideas and findings, encouraging the sharing of teaching best practices, and supporting the development of high quality curriculum.

The International Association for Computer Information Systems (IACIS) is a nonprofit association founded in 1960 and dedicated to the improvement of information systems and the education of information systems and computer professionals. These goals are accomplished through various activities, recognition awards, and publications." (IACIS, 2018).

IACIS and IIS are thus a significant and important forum for the exchange of current topics related to information systems, computer science, and related technology in support of business, academia, and other relevant organizations.

As we are all aware, computers and information systems have changed dramatically over the past decades. This manuscript is an attempt to review this changing landscape and determine what topics have risen and fallen over the past 18 years by analyzing the titles of articles published in IIS over its 18 year history. In the 18 years, 1906 articles were published, providing a rich dataset for the changing topics of the times. The articles were divided into three groups, 2000-2005, 2006-2011, and 2012-2017. In each of these three groups there were the following number of articles. 
Issues in Information Systems

Volume 19, Issue 1, pp. 39-47, 2018

Table 1. Articles in IIS per Time Period

\begin{tabular}{|c|c|}
\hline Year group & Number of articles \\
\hline $2000-2005$ & 604 \\
\hline $2006-2011$ & 714 \\
\hline $2012-2017$ & 588 \\
\hline
\end{tabular}

This manuscript is an attempt to review the changes that have taken place within computer and information systems over this 18 year time span by examining the count of one and two word phrases included in the titles of these articles and determining which terms increased in frequency and which decreased in frequency. These results serve as a proxy to show technologies have risen and fallen over the past 18 years. This will provide a significant research contribution by showing the recent historical trends of technologies.

The methodology used was summative content analysis. According Hsieh and Shannon (2005), there are three types of qualitative content analysis: conventional, directed, and summative". We used summative content analysis which "involves counting and comparisons, usually of keywords or content, followed by the interpretation of the underlying context" (Hsieh and Shannon, 2005).

The tracking of current technologies has a rich history in IS research. But this manuscript is unique in that it examines trends over a longer period of time (18 years) and uses a robust list of articles penned by hundreds of authors across the US and internationally. Therefore we believe this provides a unique perspective both on current important IS topics as well as a unique tracking of information technology topics over time. No other study has as large of a sample, from as diverse a group of IS experts, over as extended period of time.

\section{RESULTS}

The results of the title analysis is presented in the following tables. The first series of tables show the most popular relevant two word terms that were found in each of the six year spans analyzed. The "word frequency" lists have been reviewed by the author for relevance. Non-IT related words and word phrases such as "in the" and "the use" have been excluded. Thus what follows is a review of the rise and fall of hot and cold topics in information systems. We see this also as a proxy for the trends of technologies of the past 18 years.

The Table two shows the relevant two word terms that were most frequently in IIS article titles in the periods 20002005, 2006-2011, and 2012-2017. These groups will henceforth be referred to by an abbreviated form (i.e. 2000-2005 will be referred to as 2000-05, 2006-2011 as 2006-11 and 2012-2017 as 2012-17). Each of the groups here show the top ranked terms only. The earliest group, 2000-05 has as its most frequent term, information systems. This is the most logical term used as the journal is called Issues in Information Systems. The term information systems is the most used term in each of the 6 year periods studied in this manuscript. Additionally, the two word term information system in the singular form was popular in 2000-05, being used eleven times.

In 2000-05 the e letter for electronic was a popular term with 39 occurrences of e commerce and 11 of e learning. Of the 604 articles, 50 of them had "e" in their title. Additionally, web based was mentioned 15 times. Distance learning had ten mentions. Clearly, electronic web based online activity was a major theme of this era. The only other major technology terms in the top ten were information technology (a common term used in all 18 years) and knowledge management. According to Alavi and Leidner (2001) "Knowledge management systems (KMS) refer to a class of information systems applied to managing organizational knowledge. That is, they are IT-based systems developed to support and enhance the organizational processes of knowledge creation, storage, retrieval, transfer, and application." Knowledge management has become an important topic of study with the seminal work of Alavi and Leidner (2001) in MIS Quartely with more than 11,000 citations. The final term included in the top ten terms of 2000-05 is case study. Though many other types of study are included in titles such as empirical study and exploratory study, we have retained this term since it connotes a specific form of research, the study of a specific firm, application, or case and is relevant to how research is being conducted in each of the time periods study. In 2000-05, we see that there were thirteen titles 
with case study occurrences. As we look at future periods we will see that this form of research has grown over each time period and become a more significant form of academic research.

Table 2. Top Ten Two Word Terms in IIS Titles by Year Group

\begin{tabular}{|c|c|c|c|c|c|c|c|c|}
\hline & \multicolumn{3}{|c|}{$2006-2011$} & \multicolumn{3}{|c|}{$2012-2017$} \\
\hline \multicolumn{3}{|c|}{$\begin{array}{c}2000-2005 \\
\text { 2Word }\end{array}$} & & 2Word & Occurenc & & 2Word & Occurrences \\
\hline 1 & $\begin{array}{l}\text { information } \\
\text { systems }\end{array}$ & 45 & 1 & $\begin{array}{l}\text { information } \\
\text { systems }\end{array}$ & 61 & 1 & $\begin{array}{l}\text { information } \\
\text { systems }\end{array}$ & 40 \\
\hline 2 & e commerce & 39 & \multirow[t]{2}{*}{2} & \multirow{2}{*}{$\begin{array}{l}\text { information } \\
\text { technology }\end{array}$} & \multirow[t]{2}{*}{23} & 2 & case study & 30 \\
\hline \multirow[t]{2}{*}{3} & \multirow{2}{*}{$\begin{array}{l}\text { information } \\
\text { technology }\end{array}$} & \multirow[t]{2}{*}{25} & & & & \multirow[t]{2}{*}{3} & \multirow{2}{*}{$\begin{array}{l}\text { information } \\
\text { technology }\end{array}$} & \multirow{2}{*}{18} \\
\hline & & & 3 & case study & 21 & & & \\
\hline 4 & web based & 15 & \multirow[t]{2}{*}{4} & \multirow{2}{*}{$\begin{array}{l}\text { software } \\
\text { development }\end{array}$} & \multirow[t]{2}{*}{17} & 4 & social media & 17 \\
\hline 5 & case study & 13 & & & & \multirow[t]{2}{*}{5} & \multirow{2}{*}{$\begin{array}{l}\text { knowledge } \\
\text { management }\end{array}$} & \multirow{2}{*}{17} \\
\hline 6 & e learning & 11 & \multirow[t]{2}{*}{5} & \multirow{2}{*}{$\begin{array}{l}\text { higher } \\
\text { education }\end{array}$} & \multirow[t]{2}{*}{14} & & & \\
\hline \multirow[t]{2}{*}{7} & \multirow{2}{*}{$\begin{array}{l}\text { information } \\
\text { system }\end{array}$} & \multirow[t]{2}{*}{11} & & & & \multirow[t]{2}{*}{6} & \multirow{2}{*}{$\begin{array}{l}\text { social } \\
\text { networking }\end{array}$} & \multirow{2}{*}{12} \\
\hline & & & \multirow[t]{2}{*}{6} & \multirow{2}{*}{$\begin{array}{l}\text { social } \\
\text { networking }\end{array}$} & \multirow[t]{2}{*}{14} & & & \\
\hline \multirow[t]{2}{*}{8} & \multirow{2}{*}{$\begin{array}{l}\text { distance } \\
\text { learning }\end{array}$} & \multirow[t]{2}{*}{10} & & & & \multirow[t]{2}{*}{7} & \multirow{2}{*}{$\begin{array}{l}\text { cloud } \\
\text { computing }\end{array}$} & \\
\hline & & & 7 & business & 13 & & & 11 \\
\hline 9 & knowledge & 10 & & intelligence & & 8 & big data & 11 \\
\hline & management & & 8 & e commerce & 12 & 9 & business & \\
\hline 10 & decision & 10 & 9 & supply chain & 11 & & intelligence & 10 \\
\hline & support & & 10 & e business & 11 & 10 & higher & 9 \\
\hline & & & & & & & education & \\
\hline
\end{tabular}

In the 2006-11 time period we see familiar terms such as information systems and information technology but we also see new topics and technologies. Software development had a strong presence in this time period with 17 mentions. Open source, agile, and outsourcing development are some of the top topics studied. A focus on information systems in higher education also emerged as a top five topic. The term e business has entered into the vocabulary as an alternative to ecommerce. We also see a bit of a morphing of knowledge management into business intelligence with business intelligence receiving thirteen mentions. "Business intelligence systems combine operational data with analytical tools to present complex and competitive information to planners and decision makers." This definition and subsequent article by Negash in 2004 may have spurred interest and attention from academic researchers. We also see two other new entries into our top ten, supply chain and social networking. This period of time saw the explosive growth in social networking sites and research followed into this space. Pempek,, Yermolayeva, \& Calvert in 2009 explored Facebook social networking and have achieved over 2000 citations. Supply chain as a topic had existed in business and logistics discipline for many years prior to this period, but the use of new and sophisticated tools and systems spurred interested in this as an information systems research topic.

The final and most current time period continued some major topics such as business intelligence, higher education, and social networking but also added three new topics social media, cloud computing, and big data. Social media and social media research was spurred by a 2010 article in Business Horizons by Kaplan and Haenlein that has received over 12,000 citations. Their definition is "Social Media is a group of Internet-based applications that build on the ideological and technological foundations of Web 2.0, and that allow the creation and exchange of User Generated Content." Social media are the actual applications (such as Facebook), whereas social networking is an activity using social media. Cloud computing also came into general use during this time period. Armbrust, et al. Presented A view of cloud computing in the Communications of the ACM in 2010. It has over 9000 citations. Their definition ia "Cloud computing refers to both the applications delivered as services over the Internet and the hardware and systems software in the data centers that provide those services.". The final new topic in the current time period top ten is big data. McKinsey and Co, the large consulting organization in 2011 published the most cited study on the potential and promise of big data with more than 3800 citations. (Manyika, 2011). SAS (2017) defines as follows, "Big data is a term that describes the large volume of data - both structured and unstructured - that inundates a business on a dayto-day basis. But it's not the amount of data that's important. It's what organizations do with the data that matters. Big data can be analyzed for insights that lead to better decisions and strategic business moves." 


\section{Issues in Information Systems \\ Volume 19, Issue 1, pp. 39-47, 2018}

The final section of the results analysis for the two word terms (tables 3, 4, and 5) studies how the top ten terms in each of the six year time periods has either grown or fallen over time. Each table shows the top ten for each period and how many mentions the terms had in the other time periods. First we examine the 2000-05 period. The largest decline in mentions is for e commerce. In 2000-05, e commerce was the second most frequent term in IIS titles with 39 occurrences. This declined to 12 in 2006-11, and only 5 in 2012-17. Clearly, there is a maturing of this topic and new research has slowed dramatically. The term web based, the fourth most popular term in 2000-05 has literally dropped off the IS vocabulary. There were NO titles using that term in 2012-17. With the ubiquity of the web, this term has become in many ways meaningless. Case study, as noted, has grown considerably over the eighteen year time period growing from 13 mentions to 21 to 30. E-learning, decision support, distance learning, and the singular use of information system have shown precipitous declines over the time periods.

Table 3. Two Word Occurrences based on 2000-2005 Ranking

\begin{tabular}{|l|l|l|l|l|}
\hline $\begin{array}{l}\text { 2000-2005 } \\
\text { Ranking }\end{array}$ & Some top phrases containing 2 words & $\mathbf{2 0 0 0 - 2 0 0 5}$ Occurrences & $\mathbf{2 0 0 6 - 2 0 1 1}$ & $\mathbf{2 0 1 2 - 2 0 1 7}$ \\
\hline 1 & information systems & 45 & 61 & 40 \\
\hline 2 & e commerce & 39 & 12 & 5 \\
\hline 3 & information technology & 25 & 23 & 18 \\
\hline 4 & web based & 15 & 5 & 0 \\
\hline 5 & case study & 13 & 21 & 30 \\
\hline 6 & e learning & 11 & 7 & 3 \\
\hline 7 & information system & 11 & 4 & 4 \\
\hline 8 & distance learning & 10 & 0 & 3 \\
\hline 9 & knowledge management & 10 & 7 & 17 \\
\hline 10 & decision support & 10 & 6 & 3 \\
\hline
\end{tabular}

When we look at terms from our middle years' perspective (table 4), we see strong new showings for social networking and business intelligence. Both of these topics had no mentions in the 2000-05 titles and both had their strongest showing in the initial posting. Both had small declines in the 2012-17 years, exhibiting a bit of a boom and bust in this period. Supply chain also exhibited a bit of this same behavior rising from 3 to 11 but falling to 4 in 2012-17.

Table 4. Two Word Occurrences based on 2006-201 Ranking

\begin{tabular}{|l|l|l|l|l|}
\hline $\mathbf{2 0 0 0 - 2 0 0 5}$ & Some top phrases containing 2 words & $\begin{array}{l}\mathbf{2 0 0 6 - 2 0 1 1} \\
\text { Ranking }\end{array}$ & $\mathbf{2 0 0 6 - 2 0 1 1 ~ O c c u r r e n c e s ~}$ & $\mathbf{2 0 1 2 - 2 0 1 7}$ \\
\hline 45 & information systems & 1 & 61 & 40 \\
\hline 25 & information technology & 2 & 23 & 18 \\
\hline 13 & case study & 3 & 21 & 30 \\
\hline 7 & software development & 4 & 17 & 3 \\
\hline 6 & higher education & 5 & 14 & 9 \\
\hline 0 & social networking & 6 & 14 & 12 \\
\hline 0 & business intelligence & 7 & 13 & 10 \\
\hline 39 & e commerce & 8 & 12 & 5 \\
\hline 3 & supply chain & 9 & 11 & 4 \\
\hline 7 & e business & 10 & 11 & 0 \\
\hline
\end{tabular}

The last table shows the top ten ranking as of 2012-17 and the mentions in the two prior periods. Information systems and technology, and higher education are down slightly but remain strong. Large gains are recorded however in social media, cloud computing, case study, and big data. Knowledge management has also shown a surprising bounce back rising from seven in 2006-11 to seventeen in 2012-17. 
Issues in Information Systems

Volume 19, Issue 1, pp. 39-47, 2018

Table 5. Two Word Occurrences based on 2012-2017 Ranking

\begin{tabular}{|l|l|l|l|l|}
\hline $\mathbf{2 0 0 0 - 2 0 0 5}$ & $\mathbf{2 0 0 6 - 2 0 1 1}$ & Some top phrases containing 2 words & $\begin{array}{l}\mathbf{2 0 1 2 - 2 0 1 7} \\
\text { Ranking }\end{array}$ & 2012-2017 Occurrences \\
\hline 45 & 61 & information systems & 1 & 40 \\
\hline 13 & 21 & case study & 2 & 30 \\
\hline 25 & 23 & information technology & 3 & 18 \\
\hline 0 & 3 & social media & 4 & 17 \\
\hline 10 & 7 & knowledge management & 5 & 17 \\
\hline 0 & 14 & social networking & 6 & 12 \\
\hline 0 & 3 & cloud computing & 7 & 11 \\
\hline 0 & 0 & big data & 8 & 11 \\
\hline 0 & 13 & business intelligence & 9 & 10 \\
\hline 6 & 14 & higher education & 10 & 9 \\
\hline
\end{tabular}

After reviewing the insights from two word phrases, we next examined one word terms. We again excluded function words and focused on technology terms. We found that many single word terms rose to importance since they are not generally paired consistently with another non-function word. Terms such as wireless, security, and programming thus became important terms to examine. The two tables below show the results of this analysis.

Many of the one word terms echo insights found in the two word study. Information, systems, and technology were at the top four terms in each of the time periods. But there were also unique findings in this one word study. The rankings are shown in table 6. For the top two technology words, information and systems there was no change in rankings over the 18 year period. Technology was third in 2000-05 and 2012-17 but fell to fourth in the 2006-11 period. Interestingly, business started at four rose to three but is currently only ranked seven. Management has hovered between five and six. There has been many changes though, in other words in our top 10. Computer has gone from nine to eight and now off the top ten. Software has likewise dropped from eight to nine to off the list. Data, social, security, and knowledge are new to the top ten in the 2012-17 period. Internet was only on in 2000-05 and web fell from five to seven to off the list.

Table 6. Top Ten One Word Terms in IIS Titles by Year Group

\begin{tabular}{|c|c|c|c|c|c|c|c|c|}
\hline \multicolumn{3}{|c|}{$2000-2005$} & \multicolumn{3}{|c|}{ 2006-2011 } & \multicolumn{3}{|c|}{$2012-2017$} \\
\hline Order & $\begin{array}{l}\text { Unfiltered } \\
\text { word count }\end{array}$ & Occurrences & Order & $\begin{array}{l}\text { Unfiltered } \\
\text { word count }\end{array}$ & Occ & Order & $\begin{array}{l}\text { Unfiltered } \\
\text { word count }\end{array}$ & Occur \\
\hline 1 & information & 105 & \begin{tabular}{|l|l}
1 \\
\end{tabular} & information & 128 & 1 & information & 94 \\
\hline 2 & systems & 75 & 2 & systems & 96 & 2 & systems & 65 \\
\hline 3 & technology & 55 & 3 & business & 66 & 3 & technology & 56 \\
\hline 4 & business & 51 & 4 & technology & 59 & 4 & data & 55 \\
\hline 5 & web & 43 & 5 & management & 53 & 5 & social & 51 \\
\hline 6 & management & 43 & 6 & security & 43 & 6 & management & 44 \\
\hline 7 & internet & 33 & 7 & web & 41 & 7 & business & 43 \\
\hline 8 & software & 31 & 8 & computer & 37 & 8 & security & 42 \\
\hline 9 & computer & 28 & 9 & software & 37 & 9 & knowledge & 35 \\
\hline 10 & online & 25 & 10 & online & 37 & 10 & online & 35 \\
\hline
\end{tabular}

The final table shows key one word terms which have been significant on the most used technical word list. Also added are a few terms due to perceived importance in the Information Systems field. A review of these terms present interesting results. Business had 51 mentions in 2000-05, rose to 66 mentions in 2006-11 but fell to only 43 mentions in 2012-17. Facing a similar up and down was ERP (enterprise resource planning). Having only six mentions in 200005, it rose to 17 in 2006-11 but fell back to seven in 2012-17. Programming, a main stable of all IS programs, has limited but consistent research over the eighteen years with 11,12, and 13 occurrences over the time periods. The area of security has grown as a research category over the periods with 19 mentions in 2000-05, growing to 43 in 2006-11 (44 including one cybersecurity mention), and the combination of security and cybersecurity rising to 55 in 2012-17. Wireless is an area that has shown sharp decline in mentions. In 2000-05 it had nine occurrences, fell to four in 2006- 


\section{Issues in Information Systems \\ Volume 19, Issue 1, pp. 39-47, 2018}

11 and two in 2012-17. Data has grown strongly from 20 to 36 to 55. Other terms which have increased in importance are mobile, cloud, privacy and analytics. Some of common terms such as analytics, cloud and cybersecurity were not even mentioned in 2000-2005. Other terms have mixed results going up in 2006-11 and down in 2012-17. These include technology, online, computer, curriculum, enterprise database, and software. Finally, a note on 'team'. We added this term to our list since it is very often one of the most important skills that employers ask for in new employees, the ability to work in teams. Unfortunately, very few of the 1,906 articles in fact only 14 papers had team in their title. This should be a fertile area for future IS research.

Table 7. Important One Word Occurrences (Ordered by 2012-2017 Ranking)

\begin{tabular}{|c|c|c|c|c|}
\hline Order & Unfiltered word count & 2000-2005 & 2006-2011 & 2012-2017 \\
\hline 8 & information & 105 & 128 & 94 \\
\hline 13 & systems & 75 & 96 & 65 \\
\hline 14 & technology & 55 & 66 & 56 \\
\hline 15 & data & 20 & 36 & 55 \\
\hline 16 & social & 3 & 28 & 51 \\
\hline 17 & management & 43 & 53 & 44 \\
\hline 18 & business & 51 & 66 & 43 \\
\hline 19 & security & 19 & 43 & 42 \\
\hline 24 & knowledge & 17 & 24 & 35 \\
\hline 25 & online & 25 & 37 & 35 \\
\hline 29 & mobile & 4 & 18 & 31 \\
\hline 40 & computer & 28 & 37 & 23 \\
\hline 42 & curriculum & 17 & 31 & 22 \\
\hline 46 & internet & 33 & 13 & 20 \\
\hline 52 & cloud & 0 & 6 & 18 \\
\hline 57 & software & 31 & 37 & 16 \\
\hline 61 & networking & 4 & 19 & 15 \\
\hline 65 & privacy & 9 & 11 & 14 \\
\hline 67 & web & 43 & 41 & 14 \\
\hline 71 & cybersecurity & 0 & 1 & 13 \\
\hline 74 & programming & 11 & 12 & 13 \\
\hline 77 & enterprise & 9 & 16 & 12 \\
\hline 78 & analytics & 0 & 1 & 12 \\
\hline 84 & virtual & 12 & 6 & 11 \\
\hline 149 & ERP & 6 & 17 & 7 \\
\hline 157 & team & 4 & 4 & 6 \\
\hline 274 & database & 8 & 15 & 4 \\
\hline 283 & distance & 15 & 7 & 4 \\
\hline 601 & wireless & 9 & 4 & 2 \\
\hline
\end{tabular}

\section{CONCLUSION}

Our study explored the historical landscape of information systems research through a review of the 1,906 article published by Issues in Information Systems since its inception 18 years ago. The study found major changes over the 18 year time period with many terms and topics increasing significantly and others falling out of favor altogether. The study serves a comprehensive review of how much and what has changed over the past two decades.

Further statistical research can be undertaken to further study these topics. Also, additional publication sources can be reviewed to compare and validate this report's findings. 


\section{REFERENCES}

Alavi, M., \& Leidner, D. E. (2001). Knowledge management and knowledge management systems: Conceptual foundations and research issues. MIS Quarterly, 107-136.

Anthony, L. (2001). Characteristic features of research article titles in computer science. IEEE Transactions on Professional Communication, 44(3), 187-194.

Armbrust, M., Fox, A., Griffith, R., Joseph, A. D., Katz, R., Konwinski, A., ... \& Zaharia, M. (2010). A view of cloud computing. Communications of the ACM, 53(4), 50-58.

Chao, C. C., Yang, J. M., \& Jen, W. Y. (2007). Determining technology trends and forecasts of RFID by a historical review and bibliometric analysis from 1991 to 2005. Technovation, 27(5), 268-279.

Eason, K. D. (2014). Information technology and organisational change. CRC Press.

Goldzweig, C. L., Towfigh, A., Maglione, M., \& Shekelle, P. G. (2009). Costs and benefits of health information technology: new trends from the literature. Health affairs, 28(2), w282-w293.

Hammant, J. (1995). Information technology trends in logistics. Logistics Information Management, 8(6), 32-37.

Hsieh, H. F., \& Shannon, S. E. (2005). Three approaches to qualitative content analysis. Qualitative health research, 15(9), 1277-1288.

IACIS (2018). http://www.iacis.org

Issues in Information Systems (2018) http://www.iacis.org/iis/iis.php

Jacques, T. S., \& Sebire, N. J. (2010). The impact of article titles on citation hits: an analysis of general and specialist medical journals. JRSM short reports, 1(1), 1-5.

Kaplan, A. M., \& Haenlein, M. (2010). Users of the world, unite! The challenges and opportunities of Social Media. Business horizons, 53(1), 59-68.

Lee, A. R., Son, S. M., \& Kim, K. K. (2016). Information and communication technology overload and social networking service fatigue: A stress perspective. Computers in Human Behavior, 55, 51-61.

Manyika, J., Chui, M., Brown, B., Bughin, J., Dobbs, R., Roxburgh, C., \& Byers, A. H. (2011). Big data: The next frontier for innovation, competition, and productivity. McKinsey and Company. https:/www.mckinsey.com/business-functions/digital-mckinsey/our-insights/big-data-the-next-frontier-forinnovation

Martin, S., Diaz, G., Sancristobal, E., Gil, R., Castro, M., \& Peire, J. (2011). New technology trends in education: Seven years of forecasts and convergence. Computers \& Education, 57(3), 1893-1906.

Negash, S. (2004). Business intelligence. The communications of the Association for Information Systems, $13(1), 54$.

Pempek, T. A., Yermolayeva, Y. A., \& Calvert, S. L. (2009). College students' social networking experiences on Facebook. Journal of applied developmental psychology, 30(3), 227-238.

SAS (2017). Big Data. https://www.sas.com/en_us/insights/big-data/what-is-big-data.html

Sawyer, S., \& Chen, T. T. (2003). Conceptualizing information technology in the study of information systems: trends and issues. In Global and organizational discourse about Information Technology (pp. 109-131). Springer, Boston, MA. 


\section{Issues in Information Systems}

Volume 19, Issue 1, pp. 39-47, 2018

Top 10 Technology Trends for 2018: IEEE Computer Society Predicts the Future of Tech (2017) https://www.prnewswire.com/news-releases/top-10-technology-trends-for-2018-ieee-computer-societypredicts-the-future-of-tech-300571274.html 